\section{How can Strategy-as-Practice Enable Innovation under the Influence of Environmental Dynamism?}

\author{
Como a Estratégia como Prática pode Habilitar a Inovação sob Influência \\ do Dinamismo Ambiental?
}

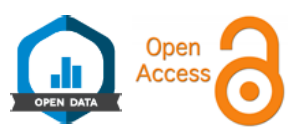

\author{
Adilson Carlos Yoshikuni*1 1 \\ José Eduardo Ricciardi Favaretto ${ }^{20}$ \\ Alberto Luiz Albertin ${ }^{10}$ \\ Fernando de Souza Meirelles ${ }^{10}$
}

\section{ABSTRACT}

Purpose: the objective of this study was to analyze innovation in Brazilian organizations when enabled through SIS, in the strategy-as-practice approach, on the influence of moderating environmental dynamism. Methods: we performed structural equation modeling using the statistical technique of partial least squares path modeling (PLS-PM) and post hoc analysis to identify unobserved heterogeneity, with a sample of 256 Brazilian companies from different sectors. Results: the results revealed that the SIS had a strong and significant influence on the innovation of exploitation and exploration. The environmental uncertainty of dynamism moderation was not present in the relationship between SIS and the innovation of exploitation. However, SIS showed a strong and significant influence on innovation of exploration in high levels of dynamism. The existence of unobserved heterogeneity was identified for two segments of the sample, demonstrating a strong path effect between SIS and innovation of exploration and exploitation on the high presence of dynamism in service companies with a size greater than 500 employees. Conclusions: the study contributed to the extension of the strategy-as-practice and innovation literature, by identifying SIS as an alternative in the planning process to enable innovation in the organization, in environments with a high rate of change and unpredictability.

Keywords: strategy-as-practice; strategic information systems; innovation of exploration and exploitation; environmental dynamism; contemporary strategic planning.

\footnotetext{
* Corresponding Author.

1. Fundação Getulio Vargas, Escola de Administração de Empresas de São Paulo, Departamento de Tecnologia e Ciência de Dados, São Paulo, SP, Brazil.

2. Escola Superior de Propaganda e Marketing, Programa de Pós-graduação em Administração, São Paulo, SP, Brazil.

Cite as: Yoshikuni, A. C., Favaretto, J. E. R., Albertin, A. L., \& Meirelles, F. de S. (2022). How can strategyas-practice enable innovation under the influence of environmental dynamism?. Revista de Administração Contemporânea, 26(1), e200131. https://doi.org/10.1590/1982-7849rac2022200131.en
}

\section{\# of invited reviewers until the decision:}

\begin{tabular}{|c|c|c|c|c|c|c|c|c|c|}
\hline & 1 & 2 & 3 & 4 & 5 & 6 & 7 & 8 & 9 \\
\hline \multicolumn{10}{|l|}{$1^{\text {st }}$ round } \\
\hline $2^{\text {nd }}$ round & (x) & $x$ & $\stackrel{\varphi}{2}$ & (x) & & & & & \\
\hline $3^{\text {rd }}$ round & $\frac{8}{2}$ & & & & & & & & \\
\hline $4^{\text {th }}$ round & $\stackrel{8}{2}$ & & & & & & & & \\
\hline
\end{tabular}

Objetivo: o objetivo deste estudo foi analisar a inovaçáo em organizaçóes brasileiras quando habilitada por meio de sistemas de informaçáo estratégicos (SIS), na abordagem de estratégia como prática, sob a influência da moderação do dinamismo. Métodos: foi utilizada a modelagem de equação estrutural pela técnica estatística de partial least squares path modeling (PLS-PM) e estudo pós-análise (post hoc analysis) para identificação da heterogeneidade não observada, com uma amostra de 256 empresas brasileiras de diferentes setores. Resultados: os resultados revelaram que o SIS apresentou influência na inovação de exploitation e exploration. A moderação do dinamismo não se apresentou na relaçáo entre o SIS e a inovaçáo de exploitation. Contudo, o SIS mostrou influência na inovaçáo de exploration em altos níveis de dinamismo. A heterogeneidade não observada foi identificada para dois segmentos da amostra, demonstrando forte efeito de caminho entre o SIS e inovação de exploration e exploitation com a alta presença de dinamismo em empresas de serviços e de tamanho superior a 500 funcionários. Conclusóes: o estudo contribuiu para a extensão da literatura de estratégia como prática e inovação, ao identificar o SIS como alternativa para habilitar a inovação na organização, em ambientes com alta taxa de mudança e imprevisibilidade.

Palavras-chave: estratégia como prática; strategic information systems; inovaçáo de exploration e exploitation; dinamismo ambiental; planejamento estratégico contemporâneo.

JEL Code: M150.

Editor-in-chief: Wesley Mendes-Da-Silva (Fundação Getulio Vargas, EAESP, Brazil) 투 Reviewers: Simone Vasconcelos Ribeiro Galina (Universidade de São Paulo, FEA-RP, Brazil) (1) Peer Review Report: The disclosure of the Peer Review Report was not authorized by its reviewer. 


\section{INTRODUCTION}

Studies by Song, Im, Van Der Bij and Song (2011) and Arend, Zhao, Song and Im (2017) have found negative effects of the strategic planning process on innovation activities. However, the evolution of strategic planning (Wolf \& Floyd, 2017) in approaches of the theoretical body of work on strategy-as-practice (Marabelli \& Galliers, 2017; Whittington, 2014) identifies the role of technology as a facilitator of agility, flexibility, and experimentation for the strategic planning process. According to Whittington (2014), the formulation, communication, execution, and monitoring of strategies adopted in organizations are inseparable from the support of strategic information systems (SIS).

Innovation studies (on exploration and exploitation innovation) first emerged from theoretical perspectives of the field of organizational learning (Jansen, Van Den Bosch, \& Volberda, 2006; March, 1991) and later reached other fields such as strategy-as-practice (Whittington, 2014; Wolf \& Floyd, 2017) and information systems (IS) (Marabelli \& Galliers, 2017; Merali, Papadopoulos, \& Nadkarni, 2012; Yoshikuni \& Albertin, 2018).

Environmental dynamism (Mikalef \& Pateli, 2017) is an external factor that pressures organizations to seek innovation (Chen, Zeng, Lin, \& Ma, 2017; Jansen et al., 2006; Jansen, Vera, \& Crossan, 2009), and that has been growing in recent years (Kamasak, Yozgat, \& Yavuz, 2017; Panda \& Rath, 2018). Companies pressured by rapidly changing business environments (environmental dynamism) reinforce the need to become innovative. A recent study on SIS using the strategy-as-practice approach (Yoshikuni \& Albertin, 2018) demonstrates positive effects of the approach in promoting the capacity and flexibility to create competitive innovation strategies in response to environmental changes.

The literature calls for research on new contexts, circumstances, and needs (Jarzabkowski \& Kaplan, 2015; Moeini, Rahrovani, \& Chan, 2019), e in search of relevant strategies in practices. The present work sought to study such phenomena (strategy-as-practice, SIS, innovation, and environmental dynamism) in the context of Brazilian organizations, on which studies of these relationships have not yet focused.

This study addresses the following research question. How can strategy-as-practice through SIS enable exploration and exploitation innovation in organizations under the influence of environmental dynamism? The study aimed to analyze how innovation in Brazilian organizations enabled through SIS via the strategy-aspractice approach moderates environmental dynamism.
The study extends the strategy-as-practice and innovation literature, addressing knowledge gaps that still exist in the field (Marabelli \& Galliers, 2017; Whittington, 2014) by identifying the SIS as an alternative to process planning in enabling innovation. Additionally, a lack of research, as mentioned in Wolf and Floyd's (2017) conceptual study, necessitates new empirical work with a focus on verifying conceptual studies of contemporary strategic planning adopting a strategy-as-practice approach. Studies by researchers of information systems (SI) (Marabelli \& Galliers, 2017; Whittington, 2014) have also noted the need for further research on SIS using this approach.

\section{LITERATURE REVIEW AND HYPOTHESES}

\section{Exploration and exploitation innovation}

First proposed by March (1991, 1995), the theory of organizational learning describes two distinct and complementary ways in which organizations learn: exploration and exploitation. Exploration initiatives are associated with activities that increase variation in organizational processes, functions, and tasks, including invention, tight control, risk taking, and solutions for new value propositions for customers, which comprise organizational aspects of search, discovery, experimentation, and risk taking (Gupta, Smith, \& Shalley, 2006; Popadiuk, 2012; Scandelari \& Cunha, 2013).

Thus, exploration activities involve experimenting with new ideas, paradigms, technologies, strategies, and knowledge to discover alternatives that can overcome or at least meet the needs of the market (Jansen et al., 2009; Lewin \& Volberda, 1999; Xue, Ray, \& Sambamurthy, 2012). Companies that position themselves with exploration innovation practices develop a capacity to frequently map the general external environment and identify factors that enhance the launch of new products and services, differentiate themselves from competitors, and establish themselves as a vanguard (Chen, Mocker, Preston, \& Teubner, 2010; Ho \& Lu, 2015; Mintzberg, Ahlstrand, \& Lampel, 2009).

Exploitation strategies are related to innovation through the use of resources, processes, and strategies of incremental innovation (March, 1991; Scandelari \& Cunha, 2013) and are designed to meet the needs of current customers and markets (Ho \& Lu, 2015; Maletič, Maletič, \& Gomišček, 2016; Popadiuk et al., 2010). Thus, the essence of exploitation innovation seeks to continuously improve existing skills, technologies, and paradigms (Gupta et al., 2006; Jansen et al., 2006). According to 
Jansen, Van Den Bosch and Volberda (2006), exploitation innovation involves improving existing products and services with frequent and minor adaptations made to the portfolio to maintain and/or expand participation in the current customer market.

Companies that adopt exploitation innovation practices develop skills that help them increase their efficiency and productivity by rationalizing the use of resources and by innovating existing products and services (Popadiuk, 2012). Exploitation innovation is characterized by risk aversion; seeking continuous improvements through existing capacities, skills, and technologies in the rationalization of business processes (Lewin \& Volberda, 1999; Popadiuk \& Bido, 2016), legitimizing standardization; and automating routines with a strong appeal to productivity in generating economies of scale (Gupta et al., 2006; Xue et al., 2012).

Typically, exploration innovations (or radical innovations) are focused on reaching customers or emerging markets and soliciting new organizational knowledge in contrast to exploitation innovations (or incremental innovations), which are designed to meet the needs of existing customers based on organizational knowledge (Benner \& Tushman, 2003).

\section{Strategic information systems (SIS) and innovation}

Seminal academic studies have shown that SIS enable strategies (Chan \& Huff, 1992; King, 1978); support business strategy processes and content (Arvidsson, Holmström, \& Lyytinen, 2014; Chen et al., 2010; Newkirk \& Lederer, 2006; Singh, Watson, \& Watson, 2002); and contribute to the survival, support, and growth of organizations (Chan, Sabherwal, \& Thatcher, 2006; Chen et al., 2014; Marabelli \& Galliers, 2017) in complex environments (Merali et al., 2012) and dynamics (Neirotti \& Raguseo, 2017).

The term SIS is treated in the academic literature on IS with several theoretical approaches (Chen et al., 2010; Merali et al., 2012), without having a single definition (Martinez-Simarro, Devece, \& Llopis-Albert, 2015; Peppard, Galliers, \& Thorogood, 2014). SIS can be seen as a set of IT/IS resources covering the collection, storage, processing, analysis, and availability of data/information to support decision-making and strategic management processes (Chan et al., 2006; Yoshikuni \& Albertin, 2018).

The definition of SIS used in this article is provided in a recent study by Yoshikuni and Albertin (2018) and highlighted by Kaplan and Norton (2008) as the IT/IS resources incorporated into the strategic planning process in the phases of strategic awareness, situation analysis, strategy design, formulation, implementation, and business strategy monitoring. Other studies on SIS have investigated their abilities to enable innovation initiatives (Chan et al., 2006; Chen et al., 2010; Johnson \& Lederer, 2013; Leidner, Lo, \& Preston, 2011; Sabherwal \& Chan, 2001) and influence external environmental dynamism (Merali et al., 2012; Mikalef \& Pateli, 2017).

The literature on SIS (Merali et al., 2012; Nan \& Tanriverdi, 2017; Pavlou \& El Sawy, 2010) reiterates the need to direct research toward addressing increased turbulence, uncertainty, and dynamism found in the competitive scenario. Although the importance of SIS to innovation has often been highlighted (Chen et al., 2010; Chuang \& Lin, 2017; Leidner et al., 2011; Sabherwal \& Chan, 2001), gaps have been identified, necessitating studies using an exploration and exploitation innovation approach enabled by SIS accounting for the influence of environmental dynamism (Pavlou \& El Sawy, 2010; Schilke, 2014).

The conceptual framework proposed by Galliers (2011) evidences theoretical ways of understanding relationships between SIS and exploration and exploitation innovation designed to support communication, collaboration, and the leveraging of knowledge processes through related organizational learning strategies in the midst of dynamism in the environment. However, no further studies (on the SIS) have analyzed this relationship and its effects using the conceptual framework proposed by Galliers (2011). A recent IS study (Teubner, 2013) highlights that organizations must react to changes imposed by uncertainty in the environment in an orchestrated and organized way, presenting SIS as an instrument of strategic knowledge management and organizational learning.

Additional studies demonstrate that SIS provide essential means for an organization to effectively develop creative and/or productivity/control initiatives (Chen et al., 2010; Merali et al., 2012). Exploration innovation focuses on a company's creativity through the generation of new products and services and through new approaches supported by SIS (Leidner et al., 2011) while exploitation innovation is enabled by SIS to develop capabilities with a focus on control or organizational efficiency and productivity (Philip, 2007; Xue et al., 2012).

According to Teubner (2013), SIS contribute to exploration innovation by enabling informal and creative processes of organizational strategies. Above all, these coordination and learning processes take place in individual planning teams at various levels of the organization, from senior management to project committees. Thus, SIS enable the communication, integration, and cooperation of 'top-down' and 'bottom-up' strategic initiatives, 
supporting target objective agreements at different levels of the company (Chen et al., 2010; Kaplan \& Norton, 2008).

The activities of exploration innovation are fueled by information captured in the external environment (Jansen et al., 2006). The SIS, through digital technologies, identify, collect, process, and analyze a large volume of data and support a company in developing cutting-edge strategies (Davenport, Harris, \& Morison, 2010; Jarzabkowski \& Kaplan, 2015; Yoshikuni \& Albertin, 2018). Thus, SIS support exploration initiatives by providing information for analyzing the life cycles of products and services and simulating the absolute nature of the portfolio and the product/service rupture curve (Merali et al., 2012).

Exploitation innovation is characterized by deliberate analyses oriented toward an objective and partially formalized by decision processes (Teubner, 2013). Exploitation initiatives are supported by IT/IS applications and predetermined operational objectives (Philip, 2007). In other words, exploitation initiatives are focused on the efficient and effective performance of activities that contribute to organizational productivity through incremental innovations (Jansen et al., 2006). Thus, control and monitoring activities are enabled by SIS and contribute to exploitation initiatives (Merali et al., 2012; Yoshikuni \& Albertin, 2018) through performance management system applications that consolidate and integrate data and information to measure the effectiveness of planned versus performed activities (Kaplan \& Norton, 2008).

In this way, SIS enable effective business strategies to create value and benefits for the process and content of exploitation innovation strategies (by developing strategies to defend the conquered market based on operational efficiency and incremental improvements in products/ services) (Philip, 2007; Yoshikuni \& Albertin, 2018) and for exploration innovation (by enabling the organization to understand and meet market changes) (Wilden \& Gudergan, 2014) and develop proactive strategies (prospecting), supporting strategic decision-making in an agile and effective way (Chan et al., 2006; Sabherwal \& Chan, 2001; Xue et al., 2012).

SIS enable flexibility and agility during the formulation of strategic planning and implementation of business strategies (Kearns \& Sabherwal, 2006; Yoshikuni \& Albertin, 2018) and exploration and exploitation innovation (Johnson \& Lederer, 2013; Marabelli \& Galliers, 2017; Merali et al., 2012). Through the lens provided by Chan and Huff (1992) and Johnson and Lederer (2013), SIS enable different strategic postures such as aggressiveness, analysis, internal and external defensiveness, externalization, futuristic planning, proactivity, risk taking, and innovation. The various strategic postures described (Chan et al., 2006) reflect exploration and exploitation innovation actions.

Thus, our hypotheses state that SIS (incorporated into business strategies) influence exploration and exploitation innovation in an organization.

H1a:SIS positively influence exploration innovation.

H1b: SIS positively influence exploitation innovation.

\section{Environmental dynamism, strategic information systems, and innovation}

Environmental dynamism has been widely studied as a factor that challenges organizations to respond quickly and flexibly to the needs of the external environment (Barbero, Ramos, \& Chiang, 2017; Chen et al., 2017; Schilke, 2014). IS researchers also highlight contextual factors that influence the relationship between SIS and organizational effectiveness (Merali et al., 2012; Newkirk \& Lederer, 2010; Ray, Wu, \& Konana, 2009; Sohn, You, Lee, \& Lee, 2003; Yayla \& Hu, 2012). The breadth and changes imposed by competition, technologies, new consumer habits, volatility, and instability in the external environment are dimensions that characterize environmental dynamism (Jansen et al., 2006; Kamasak et al., 2017; Wilhelm, Schlömer, \& Maurer, 2015).

Dynamism is defined by the level of turbulence or instability faced in an environment that provides substantial evidence of its effects on an organization's performance (Barbero et al., 2017). Environmental dynamism is defined by the rate and unpredictability of change in a company's external environment and is characterized by changes in technologies, variations in customer preferences, and fluctuations in product demand or material supply (Jansen et al., 2006, 2009).

Dynamism, as a factor of external volatility, places pressure on an organization to obtain information more quickly and to then understand and make decisions in a constantly changing environment (Chen et al., 2014; Mao, Liu, \& Zhang, 2014). Technology enables the organization to generate new knowledge and identify new opportunities by capturing market information (Dameron, Lê, \& Lebaron, 2015; George, Haas, \& Pentland, 2014; Yoshikuni \& Albertin, 2017), analyzing a broad and large volume of data (Rouhani, Ashrafi, Ravasan, \& Afshari, 2016; Shollo \& Galliers, 2016), transferring data from customers and competitors, and generating rapidly available information (Chen et al., 2014) for agile and flexible decision-making (Pavlou \& El Sawy, 2006, 2010) 
and for formulating and implementing exploration and exploitation initiatives (Mikalef \& Pateli, 2017).

From evidence of the presence of different levels of dynamism (high and low) (Chen et al., 2017) reflecting different moderation effects on innovation initiatives (Jansen et al., 2009) and requiring more organizational capacity to face the challenges of environmental uncertainty (Chen et al., 2014; Mao et al., 2014), and based on studies on models of the strategic alignment of technology demonstrating effects on the presence (high and low) of environmental dynamism (Mikalef \& Pateli, 2017; Newkirk \& Lederer, 2006, 2010; Yayla \& Hu, 2012), two additional hypotheses were formulated.

H2a: The positive influence of SIS and exploration innovation will be strongest when environmental dynamism is high.
H2b: The positive influence of SIS and exploitation innovation will be strongest when environmental dynamism is high.

An organization's decision-making in the face of high dynamism can be supported by SIS adopting a 'top-down' approach emphasizing exploitation initiatives (e.g., through steering committees of innovation projects) (Arend, Zhao, Song, \& Im, 2017) and emerging initiatives characterized by the coordination and learning of teams and individuals at various organization levels via a 'bottom-up' process (Teubner, 2013).

\section{RESEARCH METHOD}

The research instrument used was developed based on the model illustrated in Figure 1 to measure variables according to the proposed operationalization and to allow for the testing of our research hypotheses.

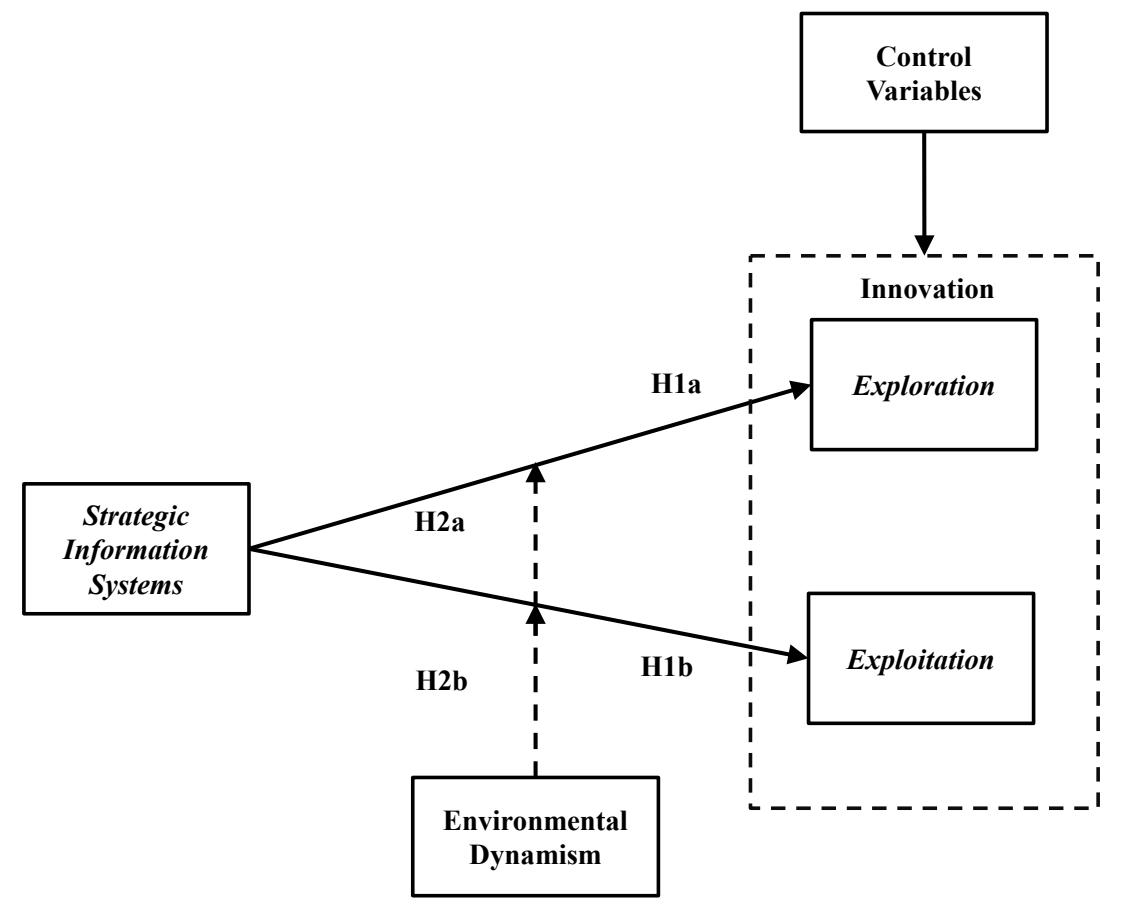

Figure 1. Conceptual research model .

Company and sector size are used as control variables. Source: Elaborated by the authors. 
The model uses variables discussed in the academic literature as described in Table 1, including the measured marker latent variable (MLMV), which was created by the authors to monitor (check) the bias of the common collection method.

We measured the exploration and exploitation innovation construct with measures and items of the organizational unit level developed by Jansen et al. (2006). The SIS measurement method used was identified from seminal studies available in the IS academic literature (Newkirk \& Lederer, 2006; Singh et al., 2002), and uses the scale already operationalized in a recent study by Yoshikuni and Albertin (2018). The Yayla e Hu (2012) scale was used to measure environmental dynamism uncertainty.

Table 1. Variables and their measurement identified from the academic literature.

\begin{tabular}{lll}
\hline Model variables & Measurement & References \\
\hline $\begin{array}{l}\text { Strategic information systems } \\
\text { Innovation (exploration and exploitation) }\end{array}$ & $\begin{array}{l}\text { IS incorporated into the strategic planning } \\
\text { process } \\
\text { Activities of exploration and exploitation }\end{array}$ & $\begin{array}{l}\text { Newkirk \& Lederer (2006); Singh, Watson, and } \\
\text { Watson (2002); Yoshikuni and Albertin (2018); }\end{array}$ \\
$\begin{array}{lll}\text { Environmental dynamism } & \text { Jnviron et al. (2006) }\end{array}$ \\
$\begin{array}{lll}\text { Control variables } & \text { Company size and sector } & \text { Yayla and Hu (2012) } \\
\text { MLMV variable } & \begin{array}{l}\text { Four indicators used by the authors to remove } \\
\text { bias from the common collection method }\end{array} & \text { Benitez, Castillo, Llorens, and Braojos (2018); } \\
\text { Benitez, Llorens, and Braojos (2018) }\end{array}$ \\
\hline
\end{tabular}

Nota. Source: Elaborated by the authors.

The scale was validated through a content analysis conducted by professors and researchers specialized in the IT/IS area with more than 10 years of teaching, academic research (with publications in journals and congresses in the field), and IT/IS consulting experience as recommended by Morgado, Meireles, Neves, Amaral and Ferreira (2018).

As suggested by Wieland, Durach, Kembro and Treiblmaier (2017), procedures were followed to ensure the rigor, reliability, validity, and parsimony of the scale items. The collection instrument (questionnaire) contained statements measured on a 7-point Likert agreement scale ranging from 1 (strongly disagree) to 7 (strongly agree) (available in Appendix A). The experts mentioned above validated all scale indicators, who made semantic adjustments to render the indicators even more understandable without affecting content validation.

With feedback obtained from the experts, it was also determined that the evaluation of the indicators pointed to the adequacy of the constructs. Following Hair, Hult, Ringle and Sarstedt (2017) recommendations, the latent variables of the proposed model had at least three indicators, allowing for the appropriate measurement of the constructs.

Following Schwarz, Rizzuto, Wolverton andRoldán (2017) recommendations on research in the field of information systems, we applied preventive procedures to minimize the bias of the collection method by choosing qualified respondents to complete the questionnaire, constructing items using clear and concise language, balancing the ordering of questions and ensuring respondents' anonymity in addition to using statistical techniques to detect and control the effects of bias during data analysis as suggested by Mackenzie and Podsakoff (2012) and Fuller, Simmering, Atinc, Atinc and Babin (2016).

As it has been recommended as a suitable operative solution for addressing collection bias in PLS models (Chin, Thatcher, Wright, \& Steel, 2013; Leal-Rodríguez, Ariza-Montes, \& Morales-fernández, 2017), the measured latent marker variable (MLMV) was used. The selected marker variable must not belong to the same domain of the constructs that shape the research model and must be obtained from a different unit of analysis (Wang \& Hajli, 2017). Thus, in applying the MLMV, the authors created four formative indicators (Chin et al., 2013), reported in Figure 2 with the weakest possible logical correlation to the other constructs of the model. We used the item level correction (ILC) procedure described in Chin et al. (2013). To confirm relationships of independence between the indicators, Pearson's correlation between the MLMV indicators was checked, revealing two statistically significant coefficients $(0.19 ; 0.13$; p-value $<0.05)$ with a very weak positive correlation (Bisquerra et al., 2004). 
MLMV_1: It is easy to achieve my goals.

MLMV_2: I will have my own business in the future.

MLMV_3: I have a positive attitude toward others.

MLMV_4: I always imagine my future home.

Figure 2. Formative indicators used for the bias analysis of the structural model.

The four indicators measuring the MLMV (measured latent marker variable) are reported as MLMV_1 to MLMV_4. Source: Elaborated by the authors.

The results show that the inclusion of the four MLMV indicators (Chin et al., 2013) did not cause significant changes in the path coefficients and explanation coefficients $\left(\mathrm{R}^{2}\right)$ of the relationships between SIS and exploration innovation and SIS and exploitation innovation. The fit values of the model are consistent with the original estimates (Table 5) and suggest that collection method bias is not a problem for this study.

\section{Data collection and sample profile}

The data used to test the research hypotheses were collected from Brazilian companies using a research instrument. The companies were selected from the directory provided by the Center for Applied Information Technology (FGVcia) of Fundação Getulio Vargas (FGV), as this center's respondents are managers and executives representing organizations of different sectors and sizes with knowledge of business management practices and technology, thus allowing us to examine our hypotheses. Additionally, the respondents were aware of the FGVcia's mission, which is to stimulate and coordinate research efforts in information technology to synergistically contribute to the generation of academic and business knowledge.

We sent 1,353 invitations via email to the organizations, and data collection was carried out using an online form (survey) available on the internet. Individuals' positions, experience, and knowledge regarding the content of the model's constructs were taken into account when choosing respondents. The sample of respondents obtained covers 256 organizations (19\% of the invitations sent), making it a convenience sample (Etikan, Musa, \& Alkassim, 2016) or nonprobabilistic or random sample of organizations from a population easily accessed by researchers. Several other studies conducted on IS (Chen et al., 2014; Gupta et al., 2006; Mikalef \& Pateli, 2017) have also used samples of convenience for empirical validation.

No missing values were identified, and no errors in questionnaire completion occurred since the internet platform used was configured to restrict errors. The existence of outliers was analyzed by the Mahalanobis square distance $\left(\mathrm{DM}^{2}\right)$ (Cousineau \& Chartier, 2017; Marôco, 2010) using SPSS software, and the sample did not show high $\mathrm{DM}^{2}$ values (maximum statistical residual of the $\mathrm{DM}^{2}$ variable $=11.756$ with a probability $\mathrm{p}$-value $<0.001$ ), indicating an absence of multivariate outliers.

We used the organization as our research analysis unit, and the respondent sample includes business and IT/IS executives who are superintendents, presidents, or directors (39\%); managers and coordinators (36\%); and supervisors with decision-making power $(25 \%)$. Table 2 describes the composition of the sampled organizations by sector and the number of employees. The sample is mainly composed of organizations from the service and industry sectors (93\% of the companies surveyed) and $40 \%$ of the organizations have 500 or more employees.

Table 2. Sample demographics — sector and number of employees.

\begin{tabular}{lllc}
\hline \multicolumn{1}{c}{ Sector } & & \multicolumn{2}{c}{ Number of employees } \\
\hline Agribusiness & $4 \%$ & $\leq 9$ & $9 \%$ \\
Government & $3 \%$ & $10-49$ & $11 \%$ \\
Industry & $36 \%$ & $50-99$ & $16 \%$ \\
Service & $57 \%$ & $100-249$ & $14 \%$ \\
& & $250-499$ & $9 \%$ \\
& & $\geq 500$ & $40 \%$ \\
\hline
\end{tabular}

Note. Source: Elaborated by the authors.

\section{EMPIRICAL RESULTS}

\section{Statistical technique}

The hypotheses were tested using partial least squares path modeling (PLS-PM) and SmartPLS v3 software (Hair, 
Hult, Ringle, \& Sarstedt, 2017). This approach proved adequate in testing the relationships between the latent variables, analyzing collection bias through formative indicators of the MLMV variable, analyzing the moderation of the continuous variable, comparing differences in path effects of the different groups of the same sample (PLSMGA), and identifying heterogeneity not observed through PLS-FIMIX and PLS-POS.

In the social sciences in general, the statistical test of 'power' should result in a value $>0.8$ (Cohen, 1988), meaning that there is at least $80 \%$ chance of finding relationships that exist (Goodhue, Lewis, \& Thompson, 2007). Researchers Peng and Lai suggest "a post hoc analysis of 'power' should be conducted to verify suitability for the study" (Peng \& Lai, 2012, p. 47). Following from this, Aguirre-Urreta and Rönkkö (2015) recommended that methodological practices for evaluating 'power' in studies using PLS could be improved with the inclusion of a 'power' analysis report. We used Aguirre-Urreta and Rönkkö (2015), approach and found consistent results for the sample of 256 cases and a 'power' value $>0.8$ from the model relationship test.

\section{Measurement model}

The latent reflexive variables were subjected to tests of reliability, convergent validity, and discriminant validity.
The estimated coefficients (outer loading) of the items show statistical significance ( $\mathrm{p}$-value $<0.001)$ and reported values above 0.7 , and items with values between 0.4 and 0.7 were maintained to increase the composite reliability (CR) and average variance extracted (AVE) as recommended by Hair, Sarstedt, Matthews and Ringle (2016) and Hair et al. (2016), confirming convergent validity (see Appendix A). All constructs show average extracted variance (AVE) values above 0.5 (Fornell \& Larcker, 1981).

The reliability of a model can be assessed by Cronbach's alpha or by composite reliability, and in the context of modeling structural equations and PLS-PM, Cronbach's alpha is sensitive to the number of items in a variable with reliability being considered more appropriate according to Hair et al. (2016). The reliability of the constructs proved to be adequate, with values of composite reliability (CR) exceeding the limit of 0.60 (Chin, 1998; Hair et al., 2017; Henseler, Ringle, \& Sinkovics, 2009). Table 3 shows that values on the diagonal (square root of the extracted average variance) are higher than those outside the diagonal (correlations), demonstrating the existence of discriminant validity (Hair et al., 2017; Ringle, Bido, \& Silva, 2014). The results of the HTMT test (heterotrait-monotrait ratio) show values below 0.85 , confirming discriminant validity as recommended by Henseler, Ringle, and Sarstedt (2015).

Table 3. Correlation matrix between constructs and other measurements.

\begin{tabular}{|c|c|c|c|c|}
\hline Construct & 1 & 2 & 3 & 4 \\
\hline 1. Environmental dynamism & 0.75 & & & \\
\hline 2. SIS & 0.40 & 0.87 & & \\
\hline 3. Exploration innovation & 0.55 & 0.60 & 0.80 & \\
\hline 4. Exploitation innovation & 0.48 & 0.67 & 0.71 & 0.76 \\
\hline Average variance extracted (AVE) & 0.56 & 0.76 & 0.64 & 0.58 \\
\hline Composite reliability (CR) & 0.79 & 0.94 & 0.90 & 0.87 \\
\hline Mean & 3.96 & 4.81 & 4.23 & 5.01 \\
\hline Standard deviation & 1.38 & 1.14 & 1.31 & 1.18 \\
\hline Cronbach's alpha (CA) & 0.67 & 0.92 & 0.86 & 0.82 \\
\hline
\end{tabular}

Note. Diagonal values denote the square root of the AVE (first block). Desirable ranges of metrics indicative of model quality = AVE $>0.5$ (Fornell \& Larcker, 1981 ); CA and CC range from 0.6 to 0.9 (Chin, 1998; Hair et al., 2017; Henseler et al., 2009). Source: Elaborated by the authors.

\section{Structural model}

The operationalization of the model involved the assessment of the moderating effect of environmental dynamism as well as the inclusion of control variables (company and sector size); see Table 4. To measure the size of the effect $\left(\mathrm{f}^{2}\right)$, the methodological literature's recommendation was followed (Cohen, 1988; Hair, Sarstedt, Ringle, \& Gudergan, 2018; Henseler et al., 2009), which suggests that effect size values of $0.02,0.15$, and 0.35 are small, moderate, and large, respectively. 
Table 4. Standardized regression coefficients of structural models with all variables.

\begin{tabular}{|c|c|c|c|c|c|c|c|}
\hline \multirow[b]{2}{*}{ Relações } & \multicolumn{2}{|r|}{ Without MLMV } & \multicolumn{5}{|c|}{ With MLMV } \\
\hline & $\mathrm{f}^{2}$ & Path coefficient & p-value & $\mathrm{R}^{2}$ & Path coefficient & p-value & $\mathrm{R}^{2}$ \\
\hline SIS $->$ Exploration & 0.331 & 0.455 & 0.000 & & 0.460 & 0.000 & \\
\hline Dynamism $\rightarrow$ Exploration & 0.235 & 0.369 & 0.000 & & 0.370 & 0.000 & \\
\hline SIS * Dynamism $\rightarrow$ Exploration & 0.043 & 0.135 & 0.000 & $51.70 \%$ & 0.137 & 0.004 & $51.80 \%$ \\
\hline Sector $->$ Exploration & 0.041 & -0.142 & 0.010 & & -0.147 & 0.004 & \\
\hline Employees $->$ Exploration & 0.002 & 0.034 & 0.459 & & 0.034 & 0.459 & \\
\hline SIS -> Exploitation & 0.484 & 0.550 & 0.000 & & 0.531 & 0.000 & \\
\hline Dynamism $\rightarrow$ Exploitation & 0.115 & 0.259 & 0.000 & & 0.255 & 0.000 & \\
\hline SIS * Dynamism $->$ Exploitation & 0.000 & 0.009 & 0.850 & $51.50 \%$ & 0.004 & 0.928 & $52.30 \%$ \\
\hline Sector $\rightarrow$ Exploitation & 0.037 & -0.135 & 0.083 & & -0.118 & 0.124 & \\
\hline Employees $\rightarrow$ Exploitation & 0.000 & -0.007 & 0.885 & & -0.008 & 0.860 & \\
\hline
\end{tabular}

Note. Sectors were measured by two formative indicators (dummy) to represent the following categories: Agribusiness, Government, Industry, and Services. Significance was estimated by bootstrapping with $\mathrm{n}=256$ cases and 5,000 repetitions in SmartPLS v3. Bias collection measurement was performed with the inclusion of MLMV indicators. Desirable ranges of metrics indicative of model quality = $\mathrm{f}^{2}$ effect size of 0.02 (small), 0.15 (moderate), or 0.35 (large) (Cohen, 1988; Henseler et al., 2009); p-value < 0.05 (Hair et al., 2017); $\mathrm{R}^{2}$ values of 0.67 (substantial), 0.33 (moderate), or 0.19 (weak) (Chin, 1998; Henseler et al., 2009). Source: Elaborated by the authors.

The possibility of heterogeneity in the sample (composed of companies from different sectors and of different sizes) was used as a justification for the inclusion of the sector and size control variables (number of employees) in the model studied. The information systems literature includes studies (Benitez, Castillo, Llorens, \& Braojos, 2018; Benitez, Llorens, \& Braojos, 2018) on the impacts of information technology (IT) on innovation using the PLSPM statistical technique and using sector and size control variables. In the research results, only the sector control variable of the dependent variable of exploration innovation shows statistical significance $(\mathrm{p}<0.01)$ with a negative path coefficient.

Hypothesis $\mathrm{H} 1 \mathrm{a}$ is supported $\left(\beta=0.455 ; \mathrm{f}^{2}=0.331\right.$; p-value $\left.<0.001 ; \mathrm{R}^{2}=51.7 \%\right)$ confirming a large and significant SIS effect of exploration innovation. Hypothesis $\mathrm{H} 1 \mathrm{~b}$ is also supported $\left(\beta=0.550 ; \mathrm{f}^{2}=0.484 ; \mathrm{p}\right.$-value $<0.001$; $\left.\mathrm{R}^{2}=51.5 \%\right)$ confirming that SIS influence exploitation innovation.

Differences in path effects of the relationships between SIS and exploration innovation and SIS and exploitation innovation were compared, and a difference of 0.095 in the structural coefficients was found.

To verify the existence of statistical significance in this difference between path coefficients of the same sample, we used the methodological framework to test differences between path coefficients following Rodríguez-Entrena, Schuberth and Gelhard (2018). Statistical significance was estimated using the bootstrap technique with 5,000 subsamples and using a 95\% confidence interval. Standard/ Student's t confidence interval, percentile bootstrap, and standard bootstrap tests verify that values between the confidence intervals are less than zero, demonstrating a lack of statistical significance ( $p$-value $>0.05$ ) for a difference of $0.095(17 \%)$ between path coefficients in the relationships of SIS -> exploration and SIS -> exploitation (see Table 5).

Table 5. Statistical significance test of two estimates of path coefficients by PLS-PM.

\begin{tabular}{lcc}
\hline $\begin{array}{l}\text { Confidence interval } \\
\text { type }(\alpha=5 \%)\end{array}$ & Inferior limit & Upper limit \\
\hline Standard & -0.089 & -0.077 \\
Percentile & -0.196 & 0.019 \\
Basic & -0.194 & 0.021 \\
\hline
\end{tabular}

Note. Source: Elaborated by the authors.

Hypothesis $\mathrm{H} 2 \mathrm{~b}$ is not supported $(\beta=0.009$; $\mathrm{f}^{2}=0.00 ; \mathrm{p}$-value $\left.>0.05 ; \mathrm{R}^{2}=51.5 \%\right)$, as the continuous dynamism variable does not show a statistically significant moderating effect on the relationship between SIS and exploitation innovation. However, for the relationship between SIS and exploration innovation, the dynamism variable shows a positive relationship and a large effect with statistical significance $\left(\beta=0.135\right.$; $\mathrm{f}^{2}=0.043$; $\mathrm{p}$-value $\left.<0.001 ; \mathrm{R}^{2}=51.7 \%\right)$, supporting hypothesis H2a. It may be that as environmental dynamism increases (for example, with an increase in a standard deviation), the relationship between SIS and exploration innovation increases with the size of the interaction term, obtaining the path coefficient value of $0.590(0.455+0.135)$ and representing a $23 \%$ increase in this relationship as shown in Figure 3. 


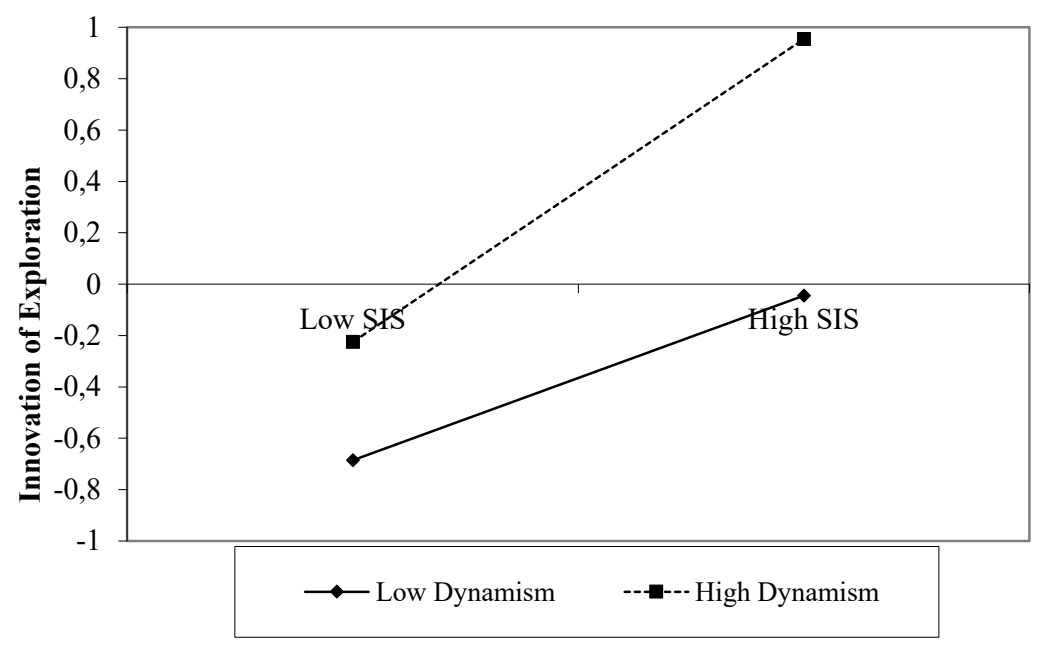

Figure 3. Graph of the moderation effect of dynamism in the relationship between SIS and exploration innovation, according to recommendations by Dawson (2014).

Source: Prepared by the authors using SmartPLS v.3 software.

\section{Post hoc analysis (post hoc analysis)}

Our post-analysis study allowed us to identify and interpret potential 'unobserved heterogeneity' in the relationship between SIS and exploration and exploitation innovation, verifying the existence of factors not included in the original analysis and that can explain differences found between the various groups of companies. The final mix technique (FIMIXPLS) was used as recommended by Hair et al. (2016) and Matthews, Sarstedt, Hair and Ringle (2016) in the PLS-PM analyses.

To identify the number of unobservable segments, the FIMIX-PLS algorithm (SmartPLS software v3) (Ringle, Wende, \& Becker, 2015), was used and performed 10 times for $\mathrm{g}=2-5$ segments using the Akaike information criteria (AIC), modified AIC with factor 3 (AIC3), Bayesian information criterion (BIC), consistent AIC (CAIC), Hannan-Quinn criterion (HQ), and standardized entropy statistics (EN), which serve as satisfactory criteria for the selection of segments.
Indicators with lower values on certain information criteria indicate the best segment solution with an EN value above 0.50 (Hair et al., 2018). According to the authors, the first criterion determines whether a combination of AIC3 and CAIC values is lower by segment. As a second criterion, the lowest AIC3 and BIC set values should be considered. As a third criterion, the lowest values are found for the combination of AIC4 and BIC. If none of the previous criteria is met, the general recommendation is to choose the segment with the lowest value as indicated by the AIC and more segments than those indicated by the criterion of the MDL5.

In addition to these criteria, the minimum sample size must be met, which in this study was identified as 50 cases, that is, the maximum number of structural paths that point to the dependent variable (5) multiplied by 10 according to criteria used in the methodological literature (Hair et al., 2017). The criteria presented in Table 6 specify that the 2 -segment solution is the most suitable, and thus, it was possible to proceed with the prediction-oriented segmentation approach (PLS-POS).

Table 6. Adjustment indices for a one to five segment solution.

\begin{tabular}{|c|c|c|c|c|c|}
\hline Criteria & & & of segments & & \\
\hline & 1 & 2 & 3 & 4 & 5 \\
\hline AIC & $1,189.43$ & $1,165.65$ & $1,143.62$ & $1,148.00$ & $1,151.54$ \\
\hline AIC3 & $1,193.43$ & $1,174.65$ & $1,157.62$ & $1,167.00$ & $1,175.54$ \\
\hline AIC4 & $1,197.43$ & $1,183.65$ & $1,171.62$ & $1,186.00$ & $1,199.54$ \\
\hline BIC & $1,203.61$ & $1,197.56$ & $1,193.25$ & $1,215.35$ & $1,236.62$ \\
\hline CAIC & $1,207.61$ & $1,206.56$ & $1,207.25$ & $1,234.35$ & $1,260.62$ \\
\hline HQ & $1,195.13$ & $1,178.49$ & $1,163.58$ & $1,175.09$ & $1,185.76$ \\
\hline MDL5 & $1,292.28$ & $1,397.19$ & $1,503.78$ & $1,636.79$ & $1,768.96$ \\
\hline EN & & 0.28 & 0.53 & 0.50 & 0.46 \\
\hline
\end{tabular}

Note. AIC — Akaike information criteria; AIC3 - AIC with modified factor 3; AIC4 - AIC with modified factor 4; BIC — Bayesian information criterion; CAIC — consisten AIC; HQ - Hannan-Quinn criterion; MDL5 - minimum description length with factor 5; EN — entropy statistics (normalized). Source: Elaborated by the authors. 
Table 7. Relative segment size.

\begin{tabular}{cccccc}
\hline $\begin{array}{c}\text { Number of } \\
\text { segments }\end{array}$ & \multicolumn{5}{c}{ Relative segment size } \\
\hline & 1 & 2 & 3 & 4 & 3 \\
2 & 0.519 & 0.481 & & & \\
3 & 0.559 & 0.283 & 0.158 & & \\
4 & 0.504 & 0.267 & 0.149 & 0.08 & \\
5 & 0.294 & 0.233 & 0.226 & 0.175 & 0.072 \\
\hline
\end{tabular}

Note. Source: Elaborated by the authors.

To assess differences in the segments and alternative solutions, the PLS-POS algorithm (SmartPLS v3 software) (Ringle et al., 2015) was performed for the two segments proposed by FIMIX-PLS, and $\mathrm{R}^{2}$ values were compared with the PLS-POS of the dependent variables (original $\mathrm{R}^{2}$, $\mathrm{R}^{2}$ 'segment 1,' $\mathrm{R}^{2}$ 'segment 2,' and mean of the $\mathrm{R}^{2}$ of the PLS-POS). Table 8 shows differences between the $\mathrm{R}^{2}$ of the original sample and the other $\mathrm{R}^{2}$ ('segment 1 ,' 'segment 2,' and the PLS-POS average), requiring complementary interpretations between the groups as recommended by the literature (Hair et al., 2018).

For the assessment of environmental dynamism in the post-analysis, we used the mean value of this variable to assign groups with low and high environmental uncertainty based on the procedure adopted in the SIS and dynamism study performed by Yayla and $\mathrm{Hu}$ (2012). Thus, values above the average of the respective dimension were considered to denote high dynamism ('high dynamism,' 147 cases), and values below the average were considered to denote low dynamism ('low dynamism,' 109 cases).

Table 9, in comparing cell counts, shows that the second segmentation (PLS-POS 'segment 2') served as the best combination for the variables of environmental dynamism, sector, and company size with an appropriate overlap of $65 \%$ found for the sample coverage as recommended in the literature (Hair et al., 2018).

Table 8. PLS-POS solution by segment.

\begin{tabular}{lllll}
\hline $\begin{array}{c}\text { Dependent } \\
\text { variable }\end{array}$ & $\begin{array}{c}\mathrm{R}^{2} \text { of the } \\
\text { original } \\
\text { sample }\end{array}$ & $\begin{array}{c}\mathrm{R}^{2} \text { of } \\
\text { segment } 1\end{array}$ & $\begin{array}{c}\mathrm{R}^{2} \text { of } \\
\text { segment } 2\end{array}$ & $\begin{array}{c}\text { Average of } \\
\mathrm{PLS}-\mathrm{POS} \\
\mathrm{R}^{2}\end{array}$ \\
\hline Exploitation & 0.447 & 0.281 & 0.732 & 0.572 \\
Exploration & 0.374 & 0.315 & 0.714 & 0.573 \\
\hline
\end{tabular}

Note. Desirable ranges of metrics indicative of model quality $=\mathrm{R}^{2}$ values of 0.67 (substantial), 0.33 (moderate), or 0.19 (weak) (Chin, 1998; Henseler et al., 2009). Source: Elaborated by the authors.

Table 9. Cross tabulation by PLS-POS segment and moderation variables.

\begin{tabular}{|c|c|c|c|c|c|c|c|}
\hline \multicolumn{2}{|c|}{ Variables } & \multicolumn{3}{|c|}{ Sample size per PLS-POS segment } & \multicolumn{2}{|c|}{$\begin{array}{l}\text { Percentage sample by segment } \\
\text { PLS-POS }\end{array}$} & \multirow{2}{*}{$\begin{array}{c}\text { Total } \\
\% \\
\end{array}$} \\
\hline & & 1 & 2 & Total & 1 & 2 & \\
\hline \multirow{2}{*}{ Dynamism } & Low & 40 & 107 & 147 & $15 \%$ & $42 \%$ & $57 \%$ \\
\hline & High & 51 & 58 & 109 & $20 \%$ & $23 \%$ & $43 \%$ \\
\hline \multirow{4}{*}{ Sectors } & Agribusiness & 5 & 6 & 11 & $2 \%$ & $2 \%$ & $4 \%$ \\
\hline & Industry & 34 & 59 & 93 & $13 \%$ & $23 \%$ & $36 \%$ \\
\hline & Service & 48 & 96 & 144 & $18 \%$ & $38 \%$ & $56 \%$ \\
\hline & Government & 4 & 4 & 8 & $2 \%$ & $2 \%$ & $3 \%$ \\
\hline \multirow{6}{*}{$\begin{array}{l}\text { Company size } \\
\text { (number of } \\
\text { employees) }\end{array}$} & Up to 9 & 10 & 13 & 23 & $4 \%$ & $5 \%$ & $9 \%$ \\
\hline & From 10 to 49 & 8 & 21 & 29 & $3 \%$ & $8 \%$ & $11 \%$ \\
\hline & From 50 to 99 & 13 & 28 & 41 & $5 \%$ & $11 \%$ & $16 \%$ \\
\hline & From 100 to 249 & 17 & 19 & 36 & $7 \%$ & $7 \%$ & $14 \%$ \\
\hline & From 250 to 499 & 13 & 11 & 24 & $4 \%$ & $4 \%$ & $9 \%$ \\
\hline & Above 500 & 30 & 73 & 103 & $12 \%$ & $29 \%$ & $40 \%$ \\
\hline
\end{tabular}

Note. Criteria used for the definition of 'high dynamism' and 'low dynamism' groups followed the procedure adopted by Yayla and Hu (2012). Source: Elaborated by the authors.

From the differences presented by the PLS-POS segment (Tables 8 and 9), the structural models for 'segment 1 ' and 'segment 2' were calculated. Table 10 presents the results of the structural models with statistical significance ( $\mathrm{p}$-value $<0.05$ ), convergent validity, and reliability according to Hair et al. (2017). Additionally, the PLS-MGA method was used to compare the path coefficients of the models to those of the original sample, revealing differences in the relationship between SIS and exploitation innovation $(|\mathrm{p} 1-\mathrm{p} 2|=0.326$; $\mathrm{t}$-value $=6.185 ; \mathrm{p}$-value $<0.001)$ and in the relationship between SIS and exploration innovation $(|\mathrm{p} 1-\mathrm{p} 2|=0.284$; $\mathrm{t}$-value $=10.463 ; \mathrm{p}$-value $<0.001$ ). 
Table 10. Aggregated results by group.

\begin{tabular}{|c|c|c|c|c|c|}
\hline Group & Structural models & Structural coefficient & Standard error & $\mathrm{p}$-value & $\mathrm{R}^{2}$ \\
\hline \multirow{2}{*}{ Original } & SIS -> Exploitation & 0.668 & 0.032 & 0.000 & $44.7 \%$ \\
\hline & SIS $\rightarrow$ Exploration & 0.612 & 0.036 & 0.000 & $37.4 \%$ \\
\hline \multirow{2}{*}{1} & SIS $->$ Exploitation & 0.530 & 0.063 & 0.000 & $28.1 \%$ \\
\hline & SIS $->$ Exploration & 0.561 & 0.246 & 0.022 & $31.5 \%$ \\
\hline \multirow{2}{*}{2} & SIS $->$ Exploitation & 0.856 & 0.018 & 0.000 & $73.2 \%$ \\
\hline & SIS $>>$ Exploration & 0.845 & 0.018 & 0.000 & $71.4 \%$ \\
\hline
\end{tabular}

Note. Desirable ranges of metrics indicative of model quality = p-value < 0.05 (Hair et al., 2017); $\mathrm{R}^{2}$ values of 0.67 (substantial), 0.33 (moderate), or 0.19 (weak) (Chin, 1998 ; Henseler et al., 2009). Source: Elaborated by the authors.

\section{DISCUSSION AND CONCLUSION}

This study examined relationships between the constructs of strategic information systems (SIS) and innovation in the midst of environmental uncertainty. The results demonstrate that the proposed model has high explanatory power, explaining more than $50 \%$ of all endogenous variables of the model.

Our results show positive effects of SIS on exploitation and exploration innovation, supporting hypotheses $\mathrm{H} 1 \mathrm{a}$ and H1b. In other words, innovation processes are enabled by strategic information systems that support evolutionary processes of innovation in a company, increasing operational efficiency in business processes, generating incremental innovation in products/services, and supporting radical innovation initiatives such as the launch of new products/ services.

Hypothesis $\mathrm{H} 2 \mathrm{~b}$ was not supported. The moderation of dynamism in the relationship between SIS and exploitation innovation was not confirmed. This result supports previous IS studies (Leidner et al., 2011; Mikalef \& Pateli, 2017), demonstrating that for IT resources used in certain configurations of environmental uncertainty, the relationship between IT and an organization's ability to meet innovation needs of the market does not change. This result suggests that even when the market is highly dynamic, companies with an incremental innovation strategy do not suffer changes due to the influence of SIS. According to Porter (1990), Mintzberg, Ahlstrand, and Lampel (2009) and Miles, Snow, Meyer, and Coleman (1978), companies that adopt incremental innovation are under pressures from the external environment to offer products and/or services with competitive prices focus on productivity (efficiency and effectiveness) to offer products and/or services with lower prices. Thus, uncertainty in the environment due to dynamism may not have any influence on the relationship between IT and exploitation innovation.
The study shows that SIS enable organizations operating in changing and unpredictable environments to quickly access information to understand and make decisions essential for radical innovation initiatives, supporting hypothesis $\mathrm{H} 2 \mathrm{a}$. In other words, companies that adopt exploration innovation experience pressures from the external environment to create new products and services, contrary to hypothesis H2b. SIS have contributed to both types of innovation (exploitation and exploration) but mainly to companies that adopt exploration innovation.

In this way, SIS can be used as an alternative means for companies to promote emerging radical innovation initiatives aligned with the deliberative direction of companies' strategic objectives, which is theorized to be essential to the strategy-as-practice approach (Bodwell \& Chermack, 2010; Bolisani \& Bratianu, 2017), and which corroborates recent research in the IS field demonstrating the role of IT in helping organizations face the effects of environmental uncertainty (Dameron et al., 2015; George et al., 2014; Rouhani et al., 2016; Yoshikuni \& Albertin, 2017).

Additionally, our post-analysis study examined unobserved heterogeneity in the sample (in two segmented groups from the original research model) and shows for 165 companies in segment 2 - greater observable variable representativeness for companies of the service sector (38\%), with more than 500 employees (29\%) and operating under high dynamism $(42 \%)$ - an increase in the path coefficients of SIS relations and exploitation innovation $(\beta=0.856$; p-value $<0.001 ; R 2=73.2 \%)$ and of SIS and exploration innovation $(\beta=0.845$; $p$-value $<0.001 ; R 2=71.4 \%)$. Such results demonstrate that in certain clusters (sector, size, and a high degree of dynamism), SIS have strong and positive effects in enabling exploitation and exploration innovation in the presence of environmental uncertainty, which is in line with IS studies demonstrating the importance of a segmented analysis of samples to identify IT value-added in business environments (Mikalef \& Pateli, 2017; Wilden \& Gudergan, 2014; Yoshikuni, Lucas, \& Albertin, 2019). 


\section{Theoretical implications}

This study extends the literature on information systems and strategy-as-practice by showing how SIS can be used as an alternative means for Brazilian organizations to integrate deliberative and emerging strategy-as-practice approaches to promote innovation in an environment of environmental uncertainty.

The study demonstrates that theoretical foundations of the strategy-as-practice approach, which can often be vague and abstract in conceptual studies, can be broken down into specific activities that can be measured with the incorporation of technological applications. In other words, the article has examined how IS applications are incorporated into strategic processes, whose aggregation and synergies encompass an organizational capacity to promote exploitation and exploration innovation. Thus, in exploring how IT can add value to strategy, especially in dynamic and turbulent environments (Kohli \& Grover, 2008), the study identifies and examines how IS applications are fundamental to promoting strategy-as-practice (taking into account recent IS and strategy-as-practice studies) (Whittington, 2014) and to enabling innovation in the organization as mentioned by Marabelli and Galliers (2017).

Additionally, the study contributes to the literature on the strategy-as-practice approach by showing that the ubiquity of IT through an SIS incorporated into the strategic process enables innovation, breaking with the rigidity paradox of strategic planning not influencing innovation mentioned in studies of strategic planning and innovation (Arend et al., 2017; Song, Im, Van Der Bij, \& Song, 2011). Thus, the study contributes to the literature on information systems and strategy-as-practice by revealing a viable alternative means through which companies can respond flexibly and quickly to the challenges of external dynamism and develop strategic initiatives of radical and incremental innovation.

\section{Practical implications}

In practice, the results of this study offer executives a clear understanding of how IS applications incorporated into strategic planning enable strategic-as-practice (deliberative and emerging strategies) in an organization to promote exploitation and exploration innovation. Thus, the study demonstrates the importance of companies investing in IS applications to promote the practice of strategy in an organization, leverage innovation, and face environmental uncertainty.

Therefore, the incorporation of IS applications into strategy activities will not only result in productivity and increase the speed of internal activities to enable incremental innovation but will also allow companies to engage in radical innovation in the face of market opportunities in new environments previously characterized by competition.

Additionally, from our post analysis results, it is evident that IS applications incorporated into the strategic process allow organizations (of different sectors and sizes and facing different levels of environmental uncertainty) to have the different stances on exploitation and exploration innovation under conditions of high dynamism.

\section{Limitations and future studies}

Despite the methodological rigor adopted in this study in structuring the collection instrument, qualifying the respondents, and handling data, nonprobabilistic sampling for convenience is considered a limitation of this study, as it does not allow for generalizations.

Future research may investigate categories that characterize the heterogeneous subgroups identified in the post-analysis section; expand our investigation of the relationship between SIS and innovation by including new constructs that enable an organization to face the challenges of dynamism; investigate whether ambidextrous innovation (simultaneous exploration and exploitation innovation) can be enabled by SIS in conditions of dynamic environmental uncertainty; and develop longitudinal studies to identify the possible formation of SIS through innovation initiatives. These little explored areas can be investigated in studies to come. 


\section{REFERENCES}

Aguirre-Urreta, M., \& Rönkkö, M. (2015). Sample size determination and statistical power analysis in PLS Using R: An annotated tutorial. Communications of the Association for Information Systems, 36(3), 33-51. https://doi.org/10.17705/1CAIS.03603

Arend, R. J., Zhao, Y. L., Song, M., \& Im, S. (2017). Strategic planning as a complex and enabling managerial tool. Strategic Management Journal, 38, 1741-1752. https://doi.org/10.1002/smj.2420.

Arvidsson, V., Holmström, J., \& Lyytinen, K. (2014). Information systems use as strategy practice : A multi-dimensional view of strategic information system implementation and use. Journal of Strategic Information Systems, 23(1), 45-61. https://doi.org/10.1016/j.jsis.2014.01.004

Barbero, J. L., Ramos, A., \& Chiang, C. (2017). Restructuring in dynamic environments: A dynamic capabilities perspective. Industrial and Corporate Change, 26(4), dtw042. https://doi.org/10.1093/icc/dtw042

Benitez, J., Castillo, A., Llorens, J., \& Braojos, J. (2018). IT-enabled knowledge ambidexterity and innovation performance in small U.S. firms: The moderator role of social media capability. Information and Management, 55(1), 131-143. https://doi.org/10.1016/j.im.2017.09.004

Benitez, J., Llorens, J., \& Braojos, J. (2018). How information technology influences opportunity exploration and exploitation firm's capabilities. Information o Management, 55(4), 508-523. https://doi.org/10.1016/j.im.2018.03.001

Benner, M. J., \& Tushman, M. L. (2003). Exploitation, exploration, and process management: The productivity dilemma revisited. Academy of Management Review, 28(2), 238 256. https://doi.org/10.5465/AMR.2003.9416096

Bisquerra, R., Sarriera, J. C., \& Martínez, F. (2004). Introdução à estatística: Enfoque informático com o pacote estatistico SPSS. São Paulo: Artmed.

Bodwell, W., \& Chermack, T. J. (2010). Organizational ambidexterity: Integrating deliberate and emergent strategy with scenario planning. Technological Forecasting and Social Change, 77(2), 193-202. https://doi.org/10.1016/j.techfore.2009.07.004

Bolisani, E., \& Bratianu, C. (2017). Knowledge strategy planning: An integrated approach to manage uncertainty, turbulence, and dynamics. Journal of Knowledge Management, 21(2), 233-253. https://doi.org/10.1108/JKM-02-2016-0071

Chan, Y. E., \& Huff, S. L. (1992). Strategy: An information systems research perspective. The Journal of Strategic Information Systems, 1(4), 191-204. https://doi.org/10.1016/0963-8687(92)90035-U

Chan, Y. E., Sabherwal, R., \& Thatcher, J. B. (2006). Antecedents and outcomes of strategic IS alignment: an empirical investigation. IEEE Transactions on Engineering Management, 53(1), 27-47. https://doi.org/10.1109/TEM.2005.861804
Chen, D. Q., Mocker, M., Preston, D. S., \& Teubner, A. (2010). Information Systems Strategy: Reconceptualization, Measurement, and Implications. MIS Quarterly, 34(2), 233-259. https://doi.org/10.2307/20721426

Chen, H., Zeng, S., Lin, H., \& Ma, H. (2017). Munificence, dynamism, and complexity: How industry context drives corporate sustainability. Business Strategy and the Environment, 26(2), 125-141. https://doi.org/10.1002/bse.1902

Chen, Y., Wang, Y., Nevo, S., Jin, J., Wang, L., \& Chow, W. S. (2014). IT capability and organizational performance: The roles of business process agility and environmental factors. European Journal of Information Systems, 23(3), 326-342. https://doi.org/10.1057/ejis.2013.4

Chin, W. W. (1998). The partial least squares approach to structural equation modeling. In G. A. Marcoulides (Ed.), Modern Methods for Business Research (pp. 295-336). Lawrence Erlbaum Associates. https://doi.org/10.1057/ejis.2013.4

Chin, W. W., Thatcher, J. B., Wright, R. T., \& Steel, D. (2013). Controlling for common method variance in PLS analysis: the measured latent marker variable approach (pp. 231239). In H Abdi, W. W. Chin, V. E. Vinzi, Russolillo, G. \& L. Trinchera (Eds.), New Perspectives in Partial Least Squares and Related Methods. New York: Springer.

Chuang, S. H., \& Lin, H. N. (2017). Performance implications of information-value offering in e-service systems: Examining the resource-based perspective and innovation strategy. Journal of Strategic Information Systems, 26(1), 22-38. https://doi.org/10.1016/j.jsis.2016.09.001

Cohen, J. (1988). Statistical power analysis for the behavioral sciences (2nd ed.). Mahwah, NJ: Lawrence Erlbaum Associates.

Cousineau,D., \&Chartier,S.(2017).Outliersdetectionand treatment: A review. International Journal of Psychological Research, 3(1), 58. https://doi.org/10.21500/20112084.844

Dameron, S., Lê, J. K., \& Lebaron, C. (2015). Materializing Strategy and Strategizing Materials: Why Matter Matters. British Journal of Management, 26, S1-S12. https://doi.org/10.1111/1467-8551.12084

Davenport, T. H., Harris, J. G., \& Morison, R. (2010). Analytics at work: Smarter decisions, better results. Brighton: Harvard Business Press.

Dawson, J. F. (2014). Moderation in management research: What, why, when, and how. Journal of Business and Psychology, 29(1), 1-19. https://doi.org/10.1007/s10869-013-9308-7

Etikan, I., Musa, S. A., \& Alkassim, R. S. (2016). Comparison of Convenience Sampling and Purposive Sampling. American Journal of Theoretical and Applied Statistics, 5(1), 1-4. https://doi.org/10.11648/j.ajtas.20160501.11

Fornell, C., \& Larcker, D. F. (1981). Evaluating structural equation models with unobservable variables and measurement error. Journal of Marketing Research, 18(1), 39-50. https://doi.org/10.2307/3151312 
Fuller, C. M., Simmering, M. J., Atinc, G., Atinc, Y., \& Babin, B. J. (2016). Common methods variance detection in business research. Journal of Business Research, 69(8), 3192-3198. https://doi.org/10.1016/j.jbusres.2015.12.008

Galliers, R. D. (2011). Further developments in information systems strategizing: Unpacking the concept. In R. D. Galliers \& W. L. Currie (Eds.), The oxford handbook of management information systems: Critical perspectives and new directions (pp. 329-345). Oxford: Oxford University Press.

George, G., Haas, M. R., \& Pentland, A. (2014). From the editors: Big data and management. Academy of Management Journal, 57(2), 321-326. https://doi.org/10.5465/amj.2014.4002

Goodhue, D., Lewis, W., \& Thompson, R. (2007). Statistical power in analyzing interaction effects: Questioning the advantage of PLS with product indicators. Information Systems Research, 18(2), 211-227. https://doi.org/10.1287/isre.1070.0123

Gupta, A. K., Smith, K. G., \& Shalley, C. E. (2006). The interplay between exploration and exploitation. Academy of Management Journal, 49(4), 693-706. https://doi.org/10.5465/AMJ.2006.22083026

Hair, J. F., Hult, G., Ringle, C., \& Sarstedt, M. (2017). A primer on partial least squares structural equation modeling (PLSSEM) (2a ed.). Thousand Oaks, CA: Sage Publications.

Hair, J. F., Sarstedt, M., Matthews, L. M., \& Ringle, C. M. (2016). Identifying and treating unobserved heterogeneity with FIMIX-PLS : Part I method. European Business Review, 28(1), 63-76. https://doi.org/10.1108/EBR-09-2015-0094

Hair, J. F., Sarstedt, M., Ringle, C. M., \& Gudergan, S. P. (2018). Advanced issues in partial least squares structural equation modeling. Thousand Oaks, CA: Sage Publications.

Henseler, J., Ringle, C. M., \& Sarstedt, M. (2015). A new criterion for assessing discriminant validity in variancebased structural equation modeling. Journal of the Academy of Marketing Science, 43(1), 115-135. https://doi.org/10.1007/s11747-014-0403-8

Henseler, J., Ringle, C.M., \& Sinkovics, R. R. (2009). The use of partial least squares path modeling in international marketing. Advances in International Marketing, 20(1), 277-319. https://doi.org/10.1108/S1474-7979(2009)0000020014

Ho, H., \& Lu, R. (2015). Performance implications of marketing exploitation and exploration: Moderating role of supplier collaboration. Journal of Business Research, 68(5), 10261034. https://doi.org/10.1016/j.jbusres.2014.10.004

Jansen, J. J. P., Van Den Bosch, F. A. J, \& Volberda, H. W. (2006). Exploratory innovation, exploitative innovation, and performance: Effects of organizational antecedents and environmental moderators. Management Science, 52(11), 1661-1674. https://doi.org/10.1287/mnsc.1060.0576

Jansen, J. J. P., Vera, D., \& Crossan, M. (2009). Strategic leadership for exploration and exploitation: The moderating role of environmental dynamism. The Leadership Quarterly, 20(1), 5-18. https://doi.org/10.1016/j.leaqua.2008.11.008
Jarzabkowski, P., \& Kaplan, S. (2015). Strategy tools-in-use: A framework for understanding 'technologies of rationality' in practice. Strategic Management Journal, 36. https://doi.org/10.1002/smj.2270

Johnson, A. M., \& Lederer, A. L. (2013). IS strategy and IS contribution: CEO and CIO perspectives. Information Systems Management, 30(4), 306-318. https://doi.org/10.1080/10580530.2013.832962

Kamasak, R., Yozgat, U., \& Yavuz, M. (2017). Knowledge process capabilities and innovation: Testing the moderating effects of environmental dynamism and strategic flexibility. Knowledge Management Research and Practice, 15(3), 356368. https://doi.org/10.1057/s41275-017-0068-4

Kaplan, R. S., \& Norton, D. P. (2008). The execution premium: Linking strategy to operations for competitive advantage. Brighton, MA: Harvard Business School Press.

Kearns, G. S., \& Sabherwal, R. (2006). Strategic Alignment Between Business and Information Technology: A KnowledgeBased View of Behaviors, Outcome, and Consequences. Journal of Management Information Systems, 23(3), 129162. https://doi.org/10.2753/MIS0742-1222230306

King, W. R. (1978). Strategic Planning for Management Information Systems. MIS Quarterly, 2(1), 27-37. https://doi.org/10.2307/249104

Kohli, R., \& Grover, V. (2008). Business value of IT: An essay on expanding research directions to keep up with the times. Journal of the Association for Information Systems, 9(1), 2339. Retrieved from https://aisel.aisnet.org/jais/vol9/iss1/1/

Leal-Rodríguez, A. L., Ariza-Montes, A. J., \& Morales-fernández, E. (2017). Green innovation, indeed a cornerstone in linking market requests and business performance. Evidence from the Spanish automotive components industry. Technological Forecasting \& Social Change, 129, 185-193. https://doi.org/10.1016/j.techfore.2017.07.021

Leidner, D. E., Lo, J., \& Preston, D. S. (2011). An empirical investigation of the relationship of IS strategy with firm performance. Journal of Strategic Information Systems, 20(4), 419-437. https://doi.org/10.1016/j.jsis.2011.09.001

Lewin, A. Y., \& Volberda, H. W. (1999). Prolegomena on coevolution: A framework for research on strategy and new organizational forms. Organization Science, 10(5), 519-534. https://doi.org/10.1287/orsc.10.5.519

MacKenzie, S. B., \& Podsakoff, P. M. (2012). Common method bias in Marketing: Causes, mechanisms, and procedural remedies. Journal of Retailing, 88(4), 542-555. https://doi.org/10.1016/j.jretai.2012.08.001

Maletič, M., Maletič, D., \& Gomišček, B. (2016). The impact of sustainability exploration and sustainability exploitation practiceson theorganisational performance:Across-country comparison. Journal of Cleaner Production, 138 (Part 1), 158-169. https://doi.org/10.1016/j.jclepro.2016.02.132

Mao, H., Liu, S., \& Zhang, J. (2014). How the effects of IT and knowledge capability on organizational agility are contingent on environmental uncertainty and information intensity. Information Development, 31(4), 1-25. https://doi.org/10.1177/0266666913518059 
Marabelli, M., \& Galliers, R. D. (2017). A reflection on information systems strategizing: The role of power and everyday practices. Information Systems Journal, 27(3), 347-366. https://doi.org/10.1111/isj.12110

March, J. G. (1991). Exploration and exploitation in organizational learning. Organization Science, 2(1), 71-87. https://doi.org/10.1287/orsc.2.1.71

March, J. G. (1995). The Future, disposable organizations and the rigidities of imagination. Organization, 2(3-4), 427-440. https://doi.org/10.1177/135050849523009

Marôco, J. (2010). Análise de equaçōes estruturais: Fundamentos teóricos, software e aplicaçôes. [S.n]: Pêro Pinheiro.

Martinez-Simarro, D., Devece, C., \& Llopis-Albert, C. (2015). How information systems strategy moderates the relationship between business strategy and performance. Journal of Business Research, 68(7), 1592-1594. https://doi.org/10.1016/j.jbusres.2015.01.057

Matthews, L. M., Sarstedt, M., Hair, J. F., \& Ringle, C. M. (2016). Identifying and treating unobserved heterogeneity with FIMIX-PLS: Part II - A case study. European Business Review, 28(2), 208-224. https://doi.org/10.1108/EBR-09-2015-0095

Merali, Y., Papadopoulos, T., \& Nadkarni, T. (2012). Systems information systems strategy: Past, present, future? Journal of Strategic Information Systems, 21(2), 125-153. https://doi.org/10.1016/j.jsis.2012.04.002

Mikalef, P., \& Pateli, A. (2017). Information technologyenabled dynamic capabilities and their indirect effect on competitive performance: Findings from PLS-SEM and fsQCA. Journal of Business Research, 70, 1-16. https://doi.org/10.1016/j.jbusres.2016.09.004

Miles, R. E., Snow, C. C., Meyer, A. D., \& Coleman, H. J. (1978). Organizational strategy Structure and Process. Academy of Management Review, 3(3), 546-562. https://doi.org/10.5465/amr.1978.4305755

Mintzberg, H., Ahlstrand, B. W., \& Lampel, J. (2009). Strategy safari: The complete guide through the wilds of strategic management (2nd ed.). Upper Saddle River: Financial Times Prentice Hall.

Moeini, M., Rahrovani, Y., \& Chan, Y. E. (2019). A review of the practical relevance of IS strategy scholarly research. Journal of Strategic Information Systems, 28(2), 196-217. https://doi.org/10.1016/j.jsis.2018.12.003

Morgado, F. F. R., Meireles, J. F. F., Neves, C. M., Amaral, A. C. S., \& Ferreira, M. E. C. (2018). Scale development: Ten main limitations and recommendations to improve future research practices. Psychology: Research and Review, 30(1), 1-20. https://doi.org/10.1186/s41155-016-0057-1

Nan, N., \& Tanriverdi, H. (2017). Unifying The role of it in hyperturbulence and competitive advantage via a multilevel perspective of IS strategy. MIS Quaterly, 41(3), 937-958. https://doi.org/10.25300/MISQ/2017/41.3.12
Neirotti, P., \& Raguseo, E. (2017). On the contingent value of IT-based capabilities for the competitive advantage of SMEs: Mechanisms and empirical evidence. Information and Management, 54(2), 139-153. https://doi.org/10.1016/j.im.2016.05.004

Newkirk, H. E., \& Lederer, A. L. (2006). The effectiveness of strategic information systems planning under environmental uncertainty. Information \& Management, 43(4), 481-501. https://doi.org/10.1016/j.im.2005.12.001

Newkirk, H. E., \& Lederer, A. (2010). The impact of environmental dynamism on strategic information systems technical and personnel resources planning. International Journal of Information Technology and Management, 9(2), 203-223. https://doi.org/10.1504/IJITM.2010.030461

Panda, S., \& Rath, S. K. (2018). Information technology capability, knowledge management capability, and organizational agility: The role of environmental factors. Journal of Management \& Organization, 1-27. https://doi.org/10.1017/jmo.2018.9

Pavlou, P. A., \& El Sawy, O. A. (2006). From IT leveraging competence to competitive advantage in turbulent environments: The case of new product development. Information Systems Research, 17(3), 198-227. https://doi.org/10.1287/isre.1060.0094

Pavlou, P. A., \& El Sawy, O. A. (2010). The 'third hand': ITenabled competitive advantage in turbulence through improvisational capabilities. Information Systems Research, 21(3), 443-471. https://doi.org/10.1287/isre.1100.0280

Peng, D. X., \& Lai, F. (2012). Using partial least squares in operations management research: A practical guideline and summary of past research. Journal of Operations Management, 30(6), 467-480. https://doi.org/10.1016/j.jom.2012.06.002

Peppard, J., Galliers, R. D., \& Thorogood, A. (2014). Information systems strategy as practice: Micro strategy and strategizing for IS. Journal of Strategic Information Systems, 23(1), 1-10. https://doi.org/10.1016/j.jsis.2014.01.002

Philip, G. (2007). IS strategic planning for operational efficiency. Information Systems Management, 24(3), 247-264. https://doi.org/10.1080/10580530701404504

Popadiuk, S. (2012). Scale for classifying organizations as explorers, exploiters or ambidextrous. International Journal of Information Management, 32(1), 75-87. https://doi.org/10.1016/j.ijinfomgt.2011.07.001

Popadiuk, S., \& Bido, D. S. (2016). Exploration, exploitation , and organizational coordination mechanisms. $R A C$ Revista de Administraçâo Contemporânea, 20(2), 238-260. https://doi.org/10.1590/1982-7849rac2016150018

Popadiuk, S., Franklin, M. A., Vidal, P. G., Miguel, L. A. P., \& Prieto, V. C. (2010). Measuring Knowledge Exploitation and Exploration: An Empirical Application in a Technological Development Center in Brazil. Revista Espacios, 31(3), 36. Retrieved from https://www.researchgate. net/publication/280883281 Measuring knowledge exploitation and exploration An empirical application in a technological development center in Brazil 
Porter, M. E. (1990). Competitive advantage: Creating and sustaining superior performance. New York: Harvard Business Review.

Ray, G., Wu, D., \& Konana, P. (2009). Competitive environment and the relationship between IT and vertical integration. Information Systems Research, 20(4), 585-603. https://doi.org/10.1287/isre.1080.0202

Ringle, C. M., Bido, D. S., \& Silva, D. (2014). Structural equation modeling with the SmartPLS. Brazilian JournalofMarketing, 13(2), 56-73. https://doi.org/10.5585/remark.v13i2.2717

Ringle, C. M., Wende, S., \& Becker, J. (2015). SmartPLS 3. Bönningstedt: SmartPLS. Retrieved from http://www.smartpls.com

Rodríguez-Entrena,M.,Schuberth,F., \&Gelhard,C.(2018).Assessing statistical differences between parameters estimates in Partial Least Squares path modeling. Quality and Quantity, 52(1), 57-69. https://doi.org/10.1007/s11135-016-0400-8

Rouhani, S., Ashrafi, A., Ravasan, A. Z., \& Afshari, S. (2016). The impact model of business intelligence on decision support and organizational benefits. Journal of Enterprise Information Management, 29(1), 19-50. https://doi.org/10.1108/JEIM-12-2014-0126

Sabherwal, R., \& Chan, Y. E. (2001). Alignment between business and IS strategies: A study of prospectors, analyzers, and defenders. Information Systems Research. https://doi.org/10.1287/isre.12.1.11.9714

Scandelari, V., \& Cunha, J. (2013). Ambidestralidade e desempenho socioambiental de empresas do setor eletroeletrônico. Journal of Business Management, 53(2), 183-198. https://doi.org/10.1590/S0034-75902013000200006

Schilke, O. (2014). On the Contingent Value of Dynamic Capabilities for Competitive Advantage: the Nonlinear Moderating Effect of Environmental Dynamism. Academy of Management Journal, 51(2), 179-203. https://doi.org/10.1002/smj.02099

Schwarz, A., Rizzuto, T., Wolverton, C. C., \& Roldán, J. L. (2017). Examining the Impact and Detection of the "Urban Legend " of Common Method Bias. ACM SIGMIS Database: The DATABASE for Advances in Information Systems, 48(1), 93119. https://doi.org/10.1145/3051473.3051479

Shollo, A., \& Galliers, R. D. (2016). Towards an understanding of the role of business intelligence systems in organisational knowing. Information Systems Journal, 26(4), 339-367. https://doi.org/10.1111/isj.12071

Singh, S. K., Watson, H. J., \& Watson, R. T. (2002). EIS support for the strategic management process. Decision Support Systems, 33(1), 71-85. https://doi.org/10.1016/S0167-9236(01)00129-4

Sohn, M. H., You, T., Lee, S. L., \& Lee, H. (2003). Corporate strategies, environmental forces, and performance measures: A weighting decision support system using the k-nearest neighbor technique. Expert Systems with Applications, 25(3), 279-292. https://doi.org/10.1016/S0957-4174(03)00070-8
Song, M., Im, S., Van Der Bij, H., \& Song, L. Z. (2011). Does strategic planning enhance or impede innovation and firm performance? Journal of Product Innovation Management, 28(4), 503-520. https://doi.org/10.1111/j.1540-5885.2011.00822.x

Teubner, R. A. (2013). Theory, Practice, and Challenges for Future Research. Business \& Information Systems Engineerin, 5(4), 243-257. https://doi.org/10.1007/s12599-013-0279-z

Wang, Y., \& Hajli, N. (2017). Exploring the path to big data analytics success in healthcare. Journal of Business Research, 70, 287299. https://doi.org/10.1016/j.jbusres.2016.08.002

Whittington, R. (2014). Information Systems Strategy and Strategy-as-Practice: A joint agenda. Journal of Strategic Information Systems, 23(1), 87-91. https://doi.org/10.1016/j.jsis.2014.01.003

Wieland, A., Durach, C. F., Kembro, J., \& Treiblmaier, H. (2017). Statistical and judgmental criteria for scale purification. Supply Chain Management: An International Journal, 22(4), 321-328. https://doi.org/10.1108/SCM-07-2016-0230

Wilden, R., \& Gudergan, S. P. (2014). The impact of dynamic capabilities on operational marketing and technological capabilities: investigating the role of environmental turbulence.Journalof the AcademyofMarketingScience, 43(2), 181-199. https://doi.org/10.1007/s11747-014-0380-y

Wilhelm, H., Schlömer, M., \& Maurer, I. (2015). How dynamic capabilities affect the effectiveness and efficiency of operating routines under high and low levels of environmental dynamism. British Journal of Management, 26(2), 327345. https://doi.org/10.1111/1467-8551.12085

Wolf, C., \& Floyd, S. W. (2017). Strategic Planning Research: Toward a Theory-Driven Agenda. Journal of Management, 43(6), 1754-1788. https://doi.org/10.1177/0149206313478185

Xue, L., Ray, G., \& Sambamurthy, V. (2012). Efficiency or Innovation: How Do Industry Environments Moderate the Effects of Firms' It Asset Portfolios? MIS Quarterly, 36(2), 509-528. https://doi.org/10.2307/41703465

Yayla, A. A., \& Hu, Q. (2012). The impact of IT-business strategic alignment on firm performance in a developing country setting: exploring moderating roles of environmental uncertainty and strategic orientation. European Journal of Information Systems, 21(4), 373-387. https://doi.org/10.1057/ejis.2011.52

Yoshikuni, A. C., \& Albertin, L. A. (2017). IT-Enabled Dynamic Capability on Performance: an Empirical Study of BSC Model. Journal of Business Management, 57(maio-jun), 215-231. https://doi.org/10.1590/S0034-759020170303

Yoshikuni, A. C., \& Albertin, A. L. (2018). Effects of strategic information systems on competitive strategy and performance. International Journal of Productivity and Performance Management, 67(9), 2018-2045. https://doi.org/10.1108/IJPPM-07-2017-0166

Yoshikuni, A. C., Lucas, E. C., \& Albertin, A. L. (2019). Strategic Information Systems Enabling Strategy-as-Practice and Corporate Performance : Empirical Evidence from PLS-PM , FIMIX-PLS and fsQCA. International Business Research, 12(1), 131-147. https://doi.org/10.5539/ibr.v12n1p131 


\section{Authorship}

\section{Adilson Carlos Yoshikuni*}

Fundação Getulio Vargas, Escola de Administração de Empresas de São Paulo, Departamento de Tecnologia e Ciência de Dados

Av. Nove de Julho, no 2029, Bela Vista, 01313-902, São Paulo, SP, Brazil.

E-mail address: ayoshikuni@terra.com.br; adilson.yoshikuni@fgv.br

(1) https://orcid.org/0000-0003-4611-6933

\section{José Eduardo Ricciardi Favaretto}

Escola Superior de Propaganda e Marketing, Programa de Pósgraduação em Administração

Rua Dr. Álvaro Alvim, no 123, Vila Mariana, 04018-010, São Paulo, SP, Brazil.

E-mail address: jose.favaretto@espm.br

(D) http://orcid.org/0000-0002-0143-0809

\section{Alberto Luiz Albertin}

Fundação Getulio Vargas, Escola de Administração de Empresas de São Paulo, Departamento de Tecnologia e Ciência de Dados Av. Nove de Julho, no 2029, Bela Vista, 01313-902, São Paulo, SP, Brazil.

E-mail address: albertin@fgv.br

(1) https://orcid.org/0000-0002-4851-0961

\section{Fernando de Souza Meirelles}

Fundação Getulio Vargas, Escola de Administração de Empresas de São Paulo, Departamento de Tecnologia e Ciência de Dados

Av. Nove de Julho, no 2029, Bela Vista, 01313-902, São Paulo, SP, Brazil.

E-mail address: fernando.meirelles@fgv.br

(1) https://orcid.org/0000-0002-0631-9800

* Corresponding Author

\section{Funding}

The authors reported that there is no financial support for the research in this article.

\section{Conflict of Interests}

The authors have stated that there is no conflict of interest.

\section{Plagiarism Check}

The RAC maintains the practice of submitting all documents approved for publication to the plagiarism check, using specific tools, e.g.: iThenticate.

\section{Copyrights}

RAC owns the copyright to this content.

\section{Authors' Contributions}

$1^{\text {st }}$ author: conceptualization (equal); data curation (lead); formal analysis (lead); investigation (lead); methodology (lead); project administration (lead); resources (equal); software (lead); supervision (lead); validation (lead); visualization (equal); writing-original draft (lead); writingreview \& editing (equal).

$2^{\text {nd }}$ author: conceptualization (equal); data curation (equal); formal analysis (equal); investigation (equal); methodology (equal); project administration (equal); resources (equal); software (equal); supervision (equal); validation (equal); visualization (equal); writing-original draft (equal); writingreview \& editing (equal).

$3^{\text {rd }}$ author: conceptualization (supporting); data curation (supporting); formal analysis (supporting); investigation (supporting); methodology (supporting); supervision (supporting); validation (supporting); writing-original draft (supporting); writing-review \& editing (equal).

$4^{\text {th }}$ author: conceptualization (supporting); formal analysis (supporting); investigation (supporting); methodology (supporting); project administration (supporting); supervision (supporting); validation (supporting); writingoriginal draft (supporting); writing-review \& editing (supporting).

\section{Peer Review Method}

This content was evaluated using the double-blind peer review process. The disclosure of the reviewers' information on the first page, as well as the Peer Review Report, is made only after concluding the evaluation process, and with the voluntary consent of the respective reviewers and authors.

\section{Data Availability}

All data and materials have been made publicly available through the Harvard Dataverse platform and can be accessed at:

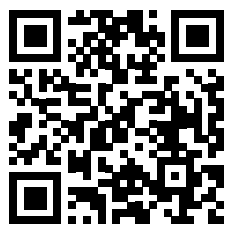

Adilson Carlos Yoshikuni; José Eduardo Ricciardi Favaretto; Alberto Luiz Albertin; Fernando de Souza Meirelles, 2020, "Replication Data for: How can strategy-as-practice enable innovation under the influence of environmental dynamism?", Harvard Dataverse, V1. https://doi.org/10.7910/DVN/ZXBMHD

RAC encourages data sharing but, in compliance with ethical principles, it does not demand the disclosure of any means of identifying research subjects, preserving the privacy of research subjects. The practice of open data is to enable the reproducibility of results, and to ensure the unrestricted transparency of the results of the published research, without requiring the identity of research subjects. 


\section{APPENDIX A. SCALE, ITEMS, AND FACTORIAL LOAD}

The p-values were estimated by bootstrap ( $\mathrm{n}=256$ and 5,000 repetitions).

Table A1. SIS items and factorial load.

\begin{tabular}{lcccc}
\hline Strategic information system (SIS) & Factorial load & Standard error & t-value & p-value \\
\hline $\begin{array}{l}\text { SIS_1 - The SIS enables the organization to disseminate and generate awareness of } \\
\text { strategic objectives. }\end{array}$ & 0.844 & 0.024 & 35.647 & 0.000 \\
$\begin{array}{l}\text { SIS_2 - The SIS enables the organization to map opportunities and threats from the } \\
\text { external environment. }\end{array}$ & 0.876 & 0.016 & 55.371 & 0.000 \\
SIS_3 - The SIS enables the company to formulate business strategies. & 0.918 & 0.010 & 90.839 & 0.000 \\
SIS_4 - The SIS enables companies to execute business strategies. & 0.842 & 0.018 & 47.805 & 0.000 \\
SIS_5 - The SIS enables the company to implement and control strategic action plans. & 0.865 & 0.019 & 44.997 & 0.000 \\
\hline
\end{tabular}

Note. This scale was obtained from Yoshikuni and Albertin (2018).

Table A2. Exploration innovation items and factorial load.

\begin{tabular}{lcccc}
\hline Exploration innovation & Factorial load & Standard error & t-value & p-value \\
\hline $\begin{array}{l}\text { INEX_1 - The company accepts demands that extend beyond those of existing products } \\
\text { and services. }\end{array}$ & (a) & & & \\
INEX_2 - The company constantly develops new products and services. & 0.834 & 0.024 & 35.072 & 0.000 \\
INEX_3 - The company launches new products and services for the local market. & 0.808 & 0.027 & 30.421 & 0.000 \\
INEX_4 - The company sells products and services that are completely new to the local unit. & 0.782 & 0.030 & 26.307 & 0.000 \\
INEX_5 - The company frequently identifies new opportunities in new markets. & 0.803 & 0.022 & 36.992 & 0.000 \\
INEX_6 - The company regularly uses new distribution channels for its products and services. & 0.762 & 0.029 & 25.882 & 0.000 \\
\hline
\end{tabular}

Note. This scale was obtained from Jansen et al. (2006). (a) This item was eliminated due to its low factor loading: INEX_1 = 0.419.

Table A3. Exploitation innovation items and factorial load.

\begin{tabular}{|c|c|c|c|c|}
\hline Exploitation innovation & Factorial load & Standard error & $\mathrm{t}$-value & $\mathrm{p}$-value \\
\hline INEP_1 - The company often improves on existing products and services. & 0.822 & 0.026 & 31.420 & 0.000 \\
\hline $\begin{array}{l}\text { INEP_2 - The company often implements minor adaptations to existing products and } \\
\text { services. }\end{array}$ & 0.725 & 0.043 & 17.089 & 0.000 \\
\hline $\begin{array}{l}\text { INEP_3 - The company introduces improvements only to existing products and services } \\
\text { in the local market. }\end{array}$ & (a) & & & \\
\hline $\begin{array}{l}\text { INEP_ } 4 \text { - The company focuses on operational efficiency in the production of products } \\
\text { and/or delivery of services. }\end{array}$ & 0.707 & 0.041 & 17.198 & 0.000 \\
\hline INEP_5 - The company is focused on increasing the market share of products and services. & 0.773 & 0.036 & 21.515 & 0.000 \\
\hline INEP_6 - The company focuses on expanding products and services for existing customers. & 0.775 & 0.036 & 21.541 & 0.000 \\
\hline
\end{tabular}

Note. This scale was obtained from Jansen et al. (2006). (a) This item was eliminated due to its low factor loading: INEP_3 $=0.119$.

Table A4. Environmental dynamism items and factorial load.

\begin{tabular}{|c|c|c|c|c|}
\hline Environmental dynamism & Factorial load & Standard error & t-value & p-value \\
\hline DINA_1 - Products and services of our sector quickly become obsolete. & 0.525 & 0.099 & 5.294 & 0.000 \\
\hline DINA_2 - The products/service technologies of our industry change rapidly. & 0.806 & 0.036 & 22.688 & 0.000 \\
\hline $\begin{array}{l}\text { DINA_3 - Rates of innovation (aimed at obtaining competitive advantages and } \\
\text { achieving business objectives) are high in our industry. }\end{array}$ & 0.875 & 0.022 & 39.834 & 0.000 \\
\hline
\end{tabular}

Note. This scale was obtained from Yayla \& Hu (2012). 